\title{
Acute lung injury and the acute respiratory distress syndrome in the injured patient
}

\author{
Magdalena Bakowitz ${ }^{1 *}$, Brandon Bruns ${ }^{2}$ and Maureen McCunn ${ }^{3}$
}

\begin{abstract}
Acute lung injury and acute respiratory distress syndrome are clinical entities of multi-factorial origin frequently seen in traumatically injured patients requiring intensive care. We performed an unsystematic search using PubMed and the Cochrane Database of Systematic Reviews up to January 2012. The purpose of this article is to review recent evidence for the pathophysiology and the management of acute lung injury/acute respiratory distress syndrome in the critically injured patient. Lung protective ventilation remains the most beneficial therapy. Future trials should compare intervention groups to controls receiving lung protective ventilation, and focus on relevant outcome measures such as duration of mechanical ventilation, length of intensive care unit stay, and mortality.
\end{abstract}

Keywords: Lung injury, Acute lung injury (ALI), Acute respiratory distress syndrome (ARDS), Trauma, Injury, Prone positioning, Extracorporeal membrane oxygenation (ECMO), Rib plating, Rib open reduction internal fixation, Flail chest, High-frequency oscillatory ventilation (HFOV), Airway pressure release ventilation (APRV)

\section{Introduction}

The Acute Respiratory Distress Syndrome (ARDS) was originally described in 1967 by Ashbaugh and Levine [1], and despite advances in diagnosis and treatment of the condition over the ensuing forty plus years, it remains a significant contributing factor to morbidity in the traumatically injured patient [2]. Survivors of ARDS have a lower functional ability and lower than normal health related quality of life two years after hospital discharge [3]. The treatment and rehabilitation of ARDS carries with it a great societal cost, and thus it remains a disease process of the utmost importance [4]. This review focuses on ALI and ARDS in the traumatically injured patient. The current definitions of acute lung injury (ALI) and acute respiratory distress syndrome (ARDS) stem from the American-European Consensus Conference, first published in 1994 [5]. The diagnosis of ALI is a clinical one and requires the presence of an acute onset, a partial pressure of arterial oxygen $\left(\mathrm{PaO}_{2}\right)$ in $\mathrm{mm} \mathrm{Hg}$ to fraction of inspired oxygen $\left(\mathrm{FiO}_{2}\right)$ ratio $(\mathrm{P} / \mathrm{F}$ ratio) of less than 300 if measured in $\mathrm{mm} \mathrm{Hg}$, or less than 40 if measured in $\mathrm{kPa}$, bilateral infiltrates on chest radiograph, and the lack of evidence of

\footnotetext{
* Correspondence: magdalena.bakowitz@uphs.upenn.edu

${ }^{1}$ Department of Anesthesiology \& Critical Care, University of Pennsylvania,

3400 Spruce Street, Philadelphia, PA 19104, USA

Full list of author information is available at the end of the article
}

cardiogenic pulmonary edema or a pulmonary artery occlusion less than or equal to $18 \mathrm{~mm} \mathrm{Hg}$ or $2.4 \mathrm{kPa}$. The definition for ARDS is the same as above, with the exception that the $\mathrm{P} / \mathrm{F}$ ratio is less than 200 if measured in $\mathrm{mm}$ $\mathrm{Hg}$ (less than 27 if measured in $\mathrm{kPa}$ ), or less than 150 if measured in $\mathrm{mm} \mathrm{Hg}$ (less than 23 if measured in $\mathrm{kPa}$ ) for severe ARDS. The definitions have been challenged since the discovery that higher $\mathrm{FiO}_{2}$ and positive end-expiratory pressure (PEEP) levels might convert patients who previously met ARDS criteria to be classified as ALI cases by $\mathrm{P} / \mathrm{F}$ ratio, and patients who previously would have been classified as ALI to carry neither lung injury diagnosis $[6,7]$.

\section{Incidence and epidemiology}

While sepsis is the most common risk factor for ALI (representing one third of cases), trauma has been identified to constitute at least $7 \%$ of cases [8]. When first studied, the incidence of ARDS did not differ between patients with blunt and penetrating mechanisms of injury, with comparable and declining mortality in both groups [9]. Over the last decade, mortality rates have continued to decrease in the general population of patients with ALI/ARDS [10,11]. The mortality of trauma-associated ALI is estimated at $24 \%[8,12,13]$. For trauma patients treated at hospitals participating in ARDS Network trials, the 60-day mortality rate is

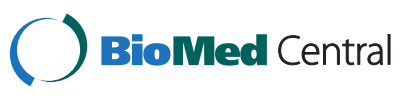


exceptionally low at $10 \%$, but has not seen any further decrease in recent years [11]. Ciesla et al. [14] however reported an encouraging decrease in the progression of ALI to ARDS and multiple organ failure (MOF) in a large single center trauma cohort. This must be considered in light of changing therapies for sepsis, cardiovascular failure, and renal replacement therapies.

A 2002 examination of ALI utilizing data from the United States showed an estimated 190,000 cases and 74,000 deaths from ALI on a yearly basis [8]. A more recent analysis of the National Trauma Databank shows the incidence of trauma-related ARDS to be $6.5 \%$ of traumatically injured patients requiring mechanical ventilation for greater than 48 hours [15]. Of patients developing ARDS, the rate of pneumonia approached $50 \%$ with crude mortality of $19 \%$. Patients spent on average 20 days on the ventilator, 22 days in the intensive care unit (ICU), and 32 days in the hospital. Total charges incurred during hospitalization were upwards of $\$ 244,000$ [15].

A 2006 retrospective review of trauma ICU data at the University of Southern California showed an overall complication rate of $43 \%$ in patients with ARDS. Complications included pneumonia, deep venous thrombosis, pulmonary embolism, acute renal failure, and disseminated intravascular coagulopathy. Additionally, ARDS patients had longer hospital stays than similarly matched controls, longer ICU stays, and higher hospital charges $(\$ 267,037$ vs. $\$ 136,680)$ [16]. Despite these differences, multiple investigators have shown no difference in mortality between ARDS patients and matched controls [16,17].

A review of blunt traumatic brain injury (TBI) patients with a head abbreviated injury score (AIS) greater than or equal to 4 showed a $7.7 \%$ incidence of ARDS. The incidence of mortality was similar in TBI patients with and without ARDS (50\% vs. $51.8 \%$ ), no significant difference in regards to discharge functional capacity between the two groups. Again, patients in the TBI + ARDS group had more complications (pneumonia, disseminated intravascular coagulation, sepsis), more time spent in the ICU, and more total hospital days [18].

ARDS following trauma is different in many respects from ARDS related to other causes. Patients with ARDS after injury tend to be younger and have fewer comorbid medical conditions [19]. Endothelial activation factor levels are lower in patients with ARDS related to trauma as opposed to septic insults [20-22]. Following cellular injury, endothelial cells can become activated, a principal mechanism in the complex pathologic events that result in ARDS. Although there is no uniform agreement on the definition of endothelial activation, inflammatory conditions lead to transcription of mRNA, altered synthesis of proteins, and a change in phenotype or function in response to stimuli from the environment [23]. Specifically, subgroup analysis of ARDS Network data has shown significantly lower levels of serum biomarkers (von Willebrand factor antigen [vWF], surfactant protein D [SP-D], tumor necrosis factor receptor-1 [TNFr-1], and intercellular adhesion molecule-1 [ICAM-1], associated with poor outcome in trauma patients [19]. Moreover, the mortality of ARDS in victims of trauma is lower than those with ARDS from other causes after adjusting for baseline differences [17].

Independent risk factors for the development of ARDS after blunt trauma are those with an injury severity score (ISS) $>25$, the presence of pulmonary contusion, a large transfusion requirement, hypotension on admission, and age $>65$ years [24]. Furthermore, investigators have shown that increasing Acute Physiology and Chronic Health Evaluation II (APACHE II) scores along with duration of mechanical ventilation are independent risk factors for the development of ARDS after trauma [25]. Some have shown specific injury patterns, such as long bone fracture and chest injury, to be independently associated [26]. Some have suggested that post-traumatic ARDS comes in two distinct forms, early ( $<48$ hours) or late ( $>48$ hours). Those developing early ARDS are characterized by a higher rate of penetrating injury, a lower admission base deficit, greater 48-hour transfusion requirement, more fluid administration in the first 5-day period, and a lower $\mathrm{P} / \mathrm{F}$ ratio on presentation; namely patients presenting in hemorrhagic shock. Patients in the late ARDS group tended to be older and had suffered a bout of pneumonia during their hospitalization [27]. The mortality rate is similar between both early and late groups $[26,27]$.

\section{Pathophysiology of ARDS}

ARDS is a progressive clinical condition in which the early phases of the disease are marked by dyspnea and hypoxemia with the appearance of radiographic infiltrates on chest radiography [28]. The development of ARDS is typically secondary to either direct lung injury (pneumonia, pulmonary contusion, inhalation injury) or indirect lung injury (overwhelming sepsis, transfusion, pancreatitis) [28] (Table 1). The clinical picture is a manifestation of the alveolar degradation and flooding with protein rich material and cellular debris with subsequent increases in pulmonary vascular resistance (Figure 1) [29]. A complex array of endothelial injury,

Table 1 Risk factors for ALI/ARDS

\begin{tabular}{ll}
\hline Primary & Secondary \\
\hline Aspiration & $\begin{array}{l}\text { Transfusion-associated } \\
\text { lung injury (TRALI) }\end{array}$ \\
Contusion & Pancreatitis \\
Pneumonia & Sepsis \\
Inhalation Injury & Traumatic Brain Injury (TBI) \\
Ventilator-Induced Lung Injury (VILI) & \\
\hline
\end{tabular}




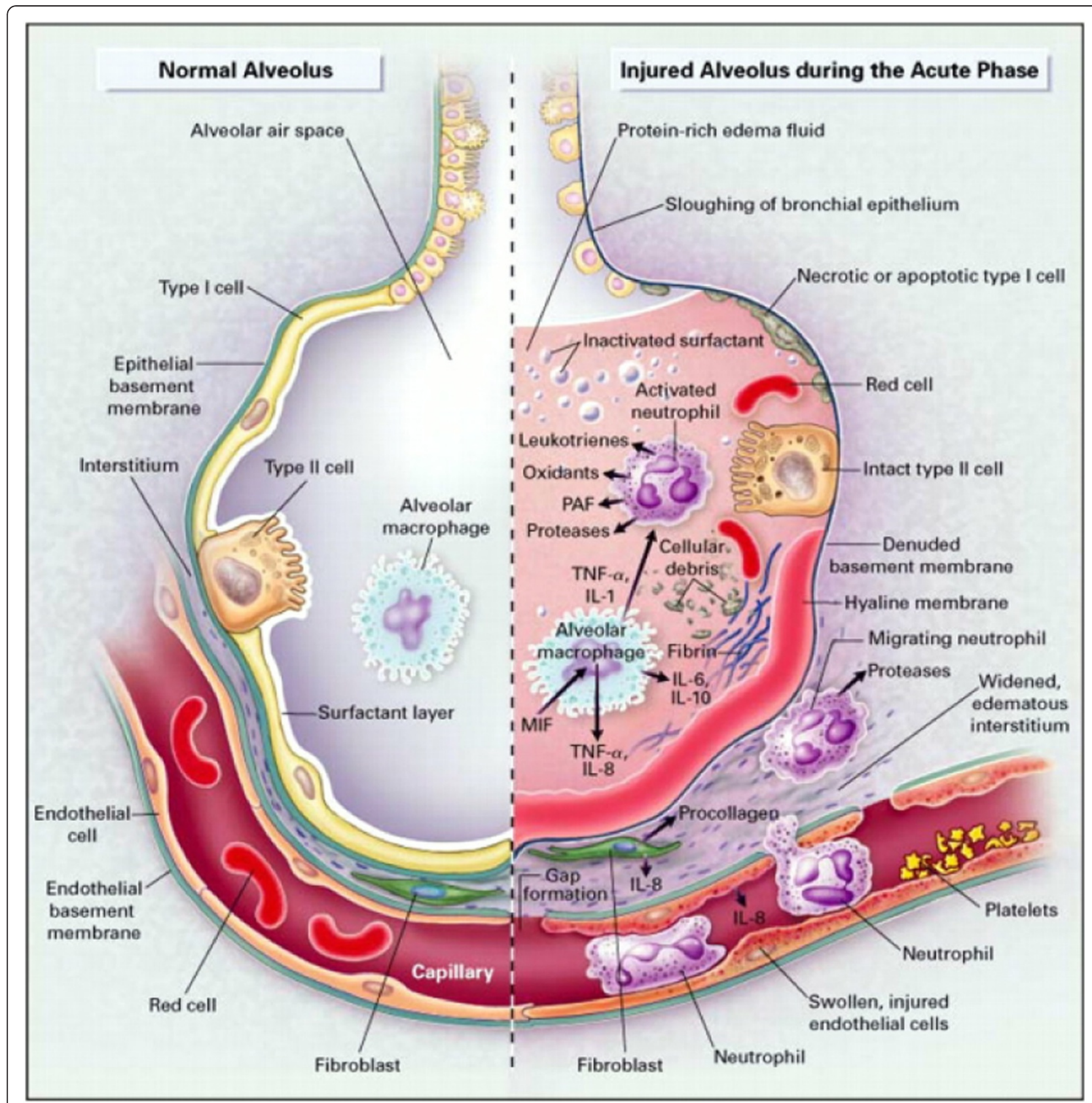

Figure 1 The normal alveolus (Left-Hand Side) and the injured alveolus in the acute phase of acute lung injury and the acute respiratory distress syndrome (Right-Hand Side). Reproduced with permission, fee paid.

epithelial injury, neutrophil-mediated damage, cytokinemediated inflammation and injury, oxidant-mediated injury, ventilator-induced lung injury, and dysregulation of the coagulation and fibrinolytic pathways are all implicated in the development of ARDS [28,29]. A proinflammatory milieu emerges in the pulmonary environment, thus leading to direct parenchymal injury and clinical deterioration (Figure 2) [29]. Severe traumatic injury is the epitome of the pro-inflammatory state, and thus ARDS is seen with increased incidence in the traumatically injured patient. ARDS may be heterogeneous and dependent, or homogeneous and diffuse, as seen in Figures 3 and 4.

\section{Transfusion practices}

Severely injured trauma patients requiring blood transfusion deserve special mention. Evidence clearly illustrates that early transfusion of packed red blood cells (PRBCs) is an independent predictor of ARDS and increases with increasing units of transfused blood [30,31]. Fresh frozen 


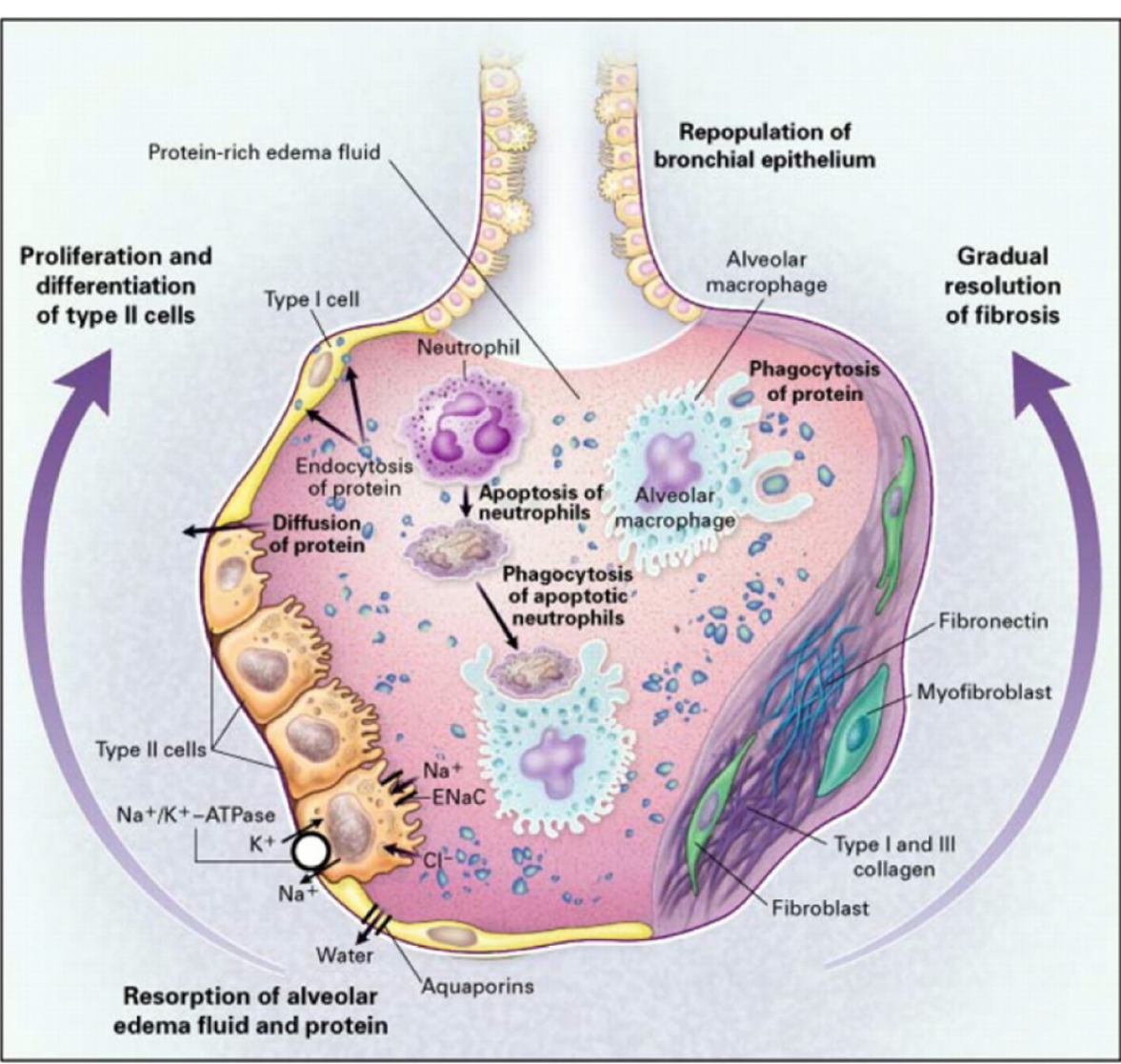

Figure 2 Mechanisms important in the resolution of acute lung injury and the acute respiratory distress syndrome. Reproduced with permission, fee paid.

plasma (FFP) has also been independently associated with a greater risk of developing ARDS, whereas platelets and cryoprecipitate were not [32]. Pre-storage leukoreduction has been attempted in an effort to minimize

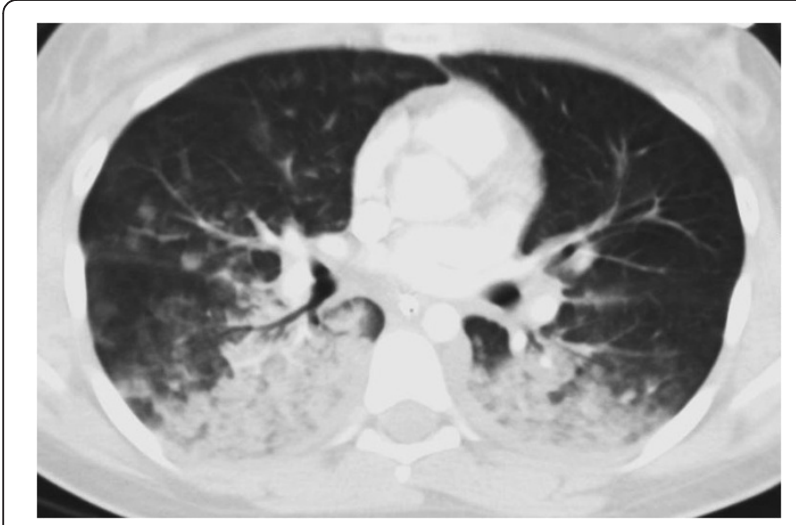

Figure 3 CT scan of same patient several hours after admission. Patient had undergone craniotomy for evacuation of intracranial hemorrhage. Intracranial pressure was not elevated post-operatively. (Atelectasis and consolidation is heterogeneous at dependent bases). the pro-inflammatory effects of residual leukocyte contamination of stored PRBCs, with the hopes of decreasing post-transfusion ARDS rates. However, randomized controlled trials have failed to show any difference in the risk of ALI or ARDS in patients receiving leukoreduced versus standard PRBCs at 28 days [33].

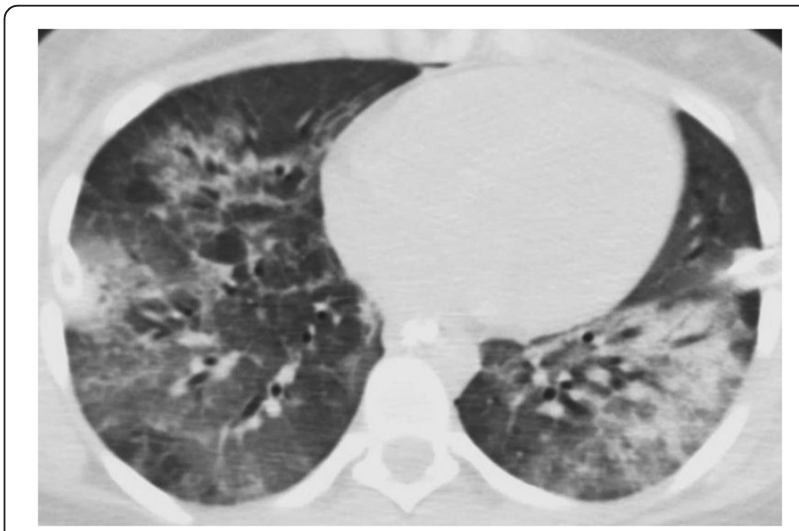

Figure 4 Same patient on hospital day 9 , following decannulation from ECMO. Consolidation is homogeneous and diffuse. 
The effect of ABO-identical versus $\mathrm{ABO}$-compatible non-identical plasma has also been explored. No difference in mortality was noted in the identical versus compatible groups. However, patients receiving ABO-compatible non-identical plasma had higher complication rates and significantly higher rates of ARDS and sepsis. Furthermore, the rates of ARDS and sepsis increased as more units of ABO-compatible non-identical plasma was transfused [34].

\section{Pulmonary contusion}

As previously mentioned, pulmonary contusion is an independent risk factor for the development of ARDS after trauma [35] and as such much attention has been paid to quantification of the degree of pulmonary contusion and its ability to alert the physician to future respiratory compromise.

Some have utilized three-dimensional computed tomography in all patients with significant thoracic injury (Figures 5 and 6). These authors showed that as the pulmonary contusion percentage exceeded $20 \%$ of total lung parenchyma, a sharp increase in the incidence of ARDS occurred [35-37]. Some suggest that this could potentially be utilized as a screening tool and enable appropriate lung protective strategies early in the patient's course. (See further discussion of pulmonary contusions under "Treatment").

\section{Race and gender differences}

Longitudinal epidemiologic studies have shown consistent differences in mortality amongst ARDS patients as a group. Males with ARDS have a persistently higher mortality rate than females with ARDS. Data would also suggest that African-American males with ARDS have a higher mortality rate than males of other racial backgrounds. Similarly, females of African-American race have a higher ARDS mortality rate than females of other racial backgrounds [22].

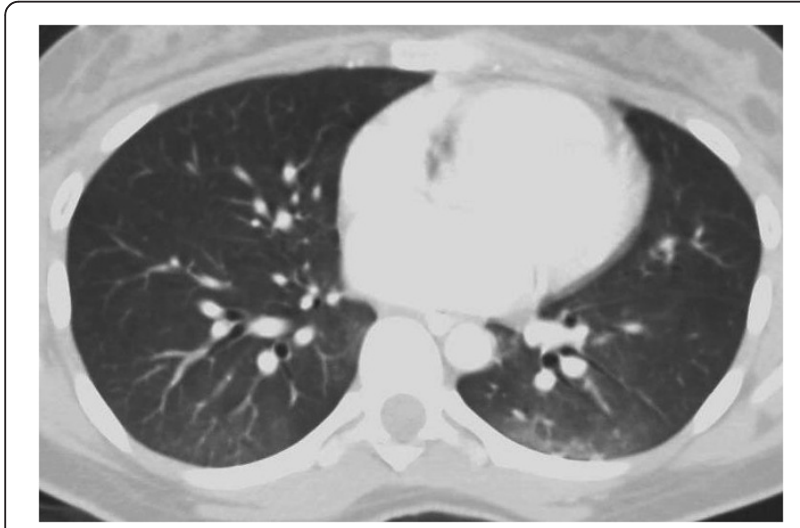

Figure 5 Admission CT scan of 18 year-old female with severe TBI (no pulmonary injuries identified).

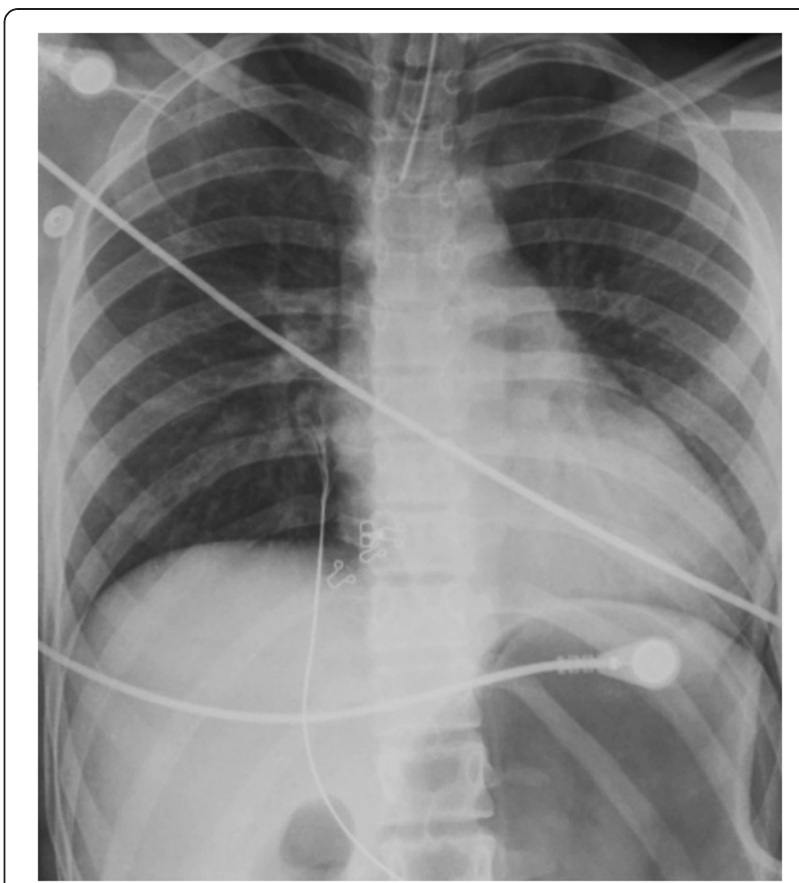

Figure 6 Corresponding admission CXR of 18 year-old female with severe TBI.

When examining ARDS after traumatic injury, investigators have shown that females are more likely to develop ARDS than their male counterparts. Despite the higher percentage of ARDS cases in females, the mortality between female and male patients with ARDS after traumatic injury does not appear to differ [38]. This data supports the concept of sex hormones, specifically estrogens, having immunologic properties enabling the development of lung injury. For both male and female patients, ARDS increases in incidence with increasing estradiol levels. Additionally, for both male and female patients, ARDS declines with increasing testosterone levels [38]. A recent study by the National Institute of Health in the United States brought awareness to a potential treatment variability [39]. Women received lung protective ventilation less frequently than men. However, after adjustment for height and severity of illness, this difference was no longer detectable.

\section{Nutrition}

The pro-inflammatory environment of the pulmonary parenchyma in ARDS patients has led some investigators to examine the effects of enteral nutrition enriched with fish oils and borage oils containing high levels of antioxidants. Early studies suggested a favorable effect on oxygenation, number of ventilator and ICU days, and a lower incidence of new organ failure [40]. These findings have been disproven by the recent OMEGA study [41], which was stopped early for futility. Twice-daily enteral 
supplementation of $\mathrm{n}-3$ fatty acids, $\gamma$-linolenic acid, and antioxidants did not improve the number of ventilatorfree days. Not all patients are able to tolerate enteral feeds after traumatic injury, thus leading some to examine the effects of total parenteral nutrition (TPN). Ventilated trauma patients receiving TPN were retrospectively analyzed over a 6-year period. TPN was independently associated with the development of late ARDS [42]. These data would suggest that the inflammatory modulation properties of the nutritional source be carefully considered in the patient at risk for ARDS.

\section{Treatment}

A number of management strategies relevant to acute lung injury with an emphasis on prevention of further deterioration are discussed below (Table 2).

It is common practice to resuscitate the trauma patient in shock with intravenous fluids even at the expense of worsening pulmonary edema. A fluid-conservative management strategy is recommended in the absence of hypotension or vasopressor requirement based on a randomized-controlled trial in medical and surgical ICU patients [43]. While this study did not measure a lower mortality rate, it also did not increase non-pulmonary organ failure. Instead, fluid restriction shortened the duration of mechanical ventilation and the length of intensive care unit stay. No randomized controlled studies exist that provide sufficient evidence to guide fluid management specific to the trauma population [44].

Pulmonary contusions can evolve over several days. Therefore, goals in the initial period are to prevent atelectasis and derecruitment (as seen in the patient in Figure 3 and 4). Incentive spirometry and patient initiated positive airway pressure therapy have been shown to decrease mechanical ventilator-dependent days, lengths of stay, infectious morbidity, and mortality in awake and cooperative patients with rib fractures assigned to a multidisciplinary pathway [45]. There is no evidence to draw conclusions on whether recruitment maneuvers independently reduce mortality or length of ventilation in patients with ALI or ARDS [46].

A retrospective review of adults with blunt traumatic pulmonary contusion in an Australian center demonstrated that noninvasive positive pressure ventilation (NIPPV) was successfully used to avoid intubation in a set of trauma patients deemed clinically appropriate despite severe pulmonary contusions and who met criteria for ARDS by $\mathrm{P} / \mathrm{F}$ ratio [47]. Of note, NIPPV was combined with a multi-modal analgesia regimen including epidural analgesia, followed by a combination of intravenous patient-controlled analgesia, non-steroidal anti-inflammatory drugs and acetaminophen. More recently, a small randomized-controlled trial in patients with thoracic trauma came to the same conclusion in regard to the use of NIPPV to avoid intubation [48]. Patients who develop frank respiratory failure (hypoxia, hypercarbia, increased work of breathing) should be intubated and mechanically ventilated without inappropriate delay. Other indications for intubation are the need for airway protection, combativeness, cardiovascular instability, to facilitate imaging and procedures, and anticipated pulmonary deterioration. Following two landmark randomized controlled trials that

Table 2 A continuum of treatment options with at times inconsistent evidence (see text for references)

\begin{tabular}{|c|c|c|c|c|}
\hline Proven benefit & $\begin{array}{l}\text { Suggested benefit } \\
\text { in select patients }\end{array}$ & $\begin{array}{l}\text { Indeterminate } \\
\text { benefit }\end{array}$ & $\begin{array}{l}\text { Suggested } \\
\text { as not } \\
\text { harmful }\end{array}$ & No benefit \\
\hline $\begin{array}{l}\text { Low tidal volumes } \\
\text { of } 6 \mathrm{ml} / \mathrm{kg} \\
\text { predicted body weight }\end{array}$ & Fluid restriction & Recruitment maneuvers & Higher PEEP & Surfactant \\
\hline PEEP $\geq 5 \mathrm{~cm} \mathrm{H}_{2} \mathrm{O}$ & $\begin{array}{l}\text { Incentive } \\
\text { spirometry }\end{array}$ & $\begin{array}{l}\text { High-frequency } \\
\text { oscillatory } \\
\text { ventilation }\end{array}$ & & $\begin{array}{l}\text { Prostaglandin } \\
\text { E1 }\end{array}$ \\
\hline \multirow[t]{6}{*}{$\begin{array}{l}\text { Plateau pressures } \leq \\
30 \mathrm{~cm} \mathrm{H}_{2} \mathrm{O}\end{array}$} & $\begin{array}{l}\text { Patient-initiated } \\
\text { positive airway } \\
\text { pressure therapy }\end{array}$ & $\begin{array}{l}\text { Airway pressure } \\
\text { release ventilation }\end{array}$ & & $\mathrm{N}$-acetylcysteine \\
\hline & $\begin{array}{l}\text { Non-invasive } \\
\text { positive pressure } \\
\text { ventilation }\end{array}$ & Steroids & & \\
\hline & $\begin{array}{l}\text { Early use of } \\
\text { neuromuscular } \\
\text { blocking agents }\end{array}$ & & & \\
\hline & $\begin{array}{l}\text { Extracorporeal } \\
\text { membrane } \\
\text { oxygenation }\end{array}$ & & & \\
\hline & Rib fracture fixation & & & \\
\hline & Prone positioning & & & \\
\hline
\end{tabular}


demonstrated a reduced mortality in patients ventilated with small volumes and low plateau pressures [49,50], small tidal volume ventilation and the use of PEEP has been accepted to maintain alveolar recruitment and oxygenation [51]. Borges et al. showed that hypoxemia can be reversed and the lung fully recruited in early ARDS [52].

A well-designed trial demonstrated that in patients ventilated with low tidal volumes, higher levels of PEEP in combination with recruitment maneuvers did neither result in a difference in hospital mortality nor in the rate of barotrauma when compared to conventional levels of PEEP [53]. The optimal level of PEEP is still unknown $[54,55]$. While PEEP usually aids in recruitment of alveoli, ventilation/perfusion mismatch can be exacerbated with ventilator pressures in unilateral lung injury as blood flow is directed away from the more compliant lung to the injured lung [56]. Patients with unilateral pulmonary contusions can progress to a clinical picture consistent with ARDS without meeting the formal criterion of bilateral infiltrates on chest $x$-ray for ARDS [5]. Posttraumatic patients at risk for or who develop ARDS should be ventilated with low tidal volumes according to ARDS Network guidelines as non-traumatized patients are.

High-frequency oscillatory ventilation avoids repeated opening and closing of lung areas by delivering cycling pressures above and below a high mean airway pressure while maintaining lung recruitment and while creating small tidal volumes of $1-4 \mathrm{ml} / \mathrm{kg}$ at a minimum of 60 times per minute $(1 \mathrm{~Hz})$. A systematic review and metaanalysis found that high frequency oscillation ventilation as an initial ventilation mode for ALI/ARDS suggests a reduced hospital and 30-day mortality compared to patients who were treated with conventional mechanical ventilation, though this evidence is not strong [57].

Airway pressure release ventilation (APRV) is the continuous administration of positive airway pressure (CPAP) to achieve recruitment with intermittent airway pressure releases to allow $\mathrm{CO}_{2}$ clearance. Patients can breathe at any point while remaining at a higher mean airway pressures [58]. It is similar to inverse ratio pressure control ventilation (IRV) with the added benefit of spontaneous breathing, and without the degree of sedation or muscle relaxation necessary for IRV [59]. APRV is an alternative mode of ventilation in patients with ALI/ARDS, but has not shown improved outcomes in mortality in large trials. It has yet to be directly compared to ventilation following the ARDS Network protocol. In a recent trial conducted by Roy et al. [60], Yorkshire pigs sustained ischemia-reperfusion injury by clamping of the superior mesenteric artery plus induced peritoneal sepsis. The animals that were immediately randomized to APRV did not develop ARDS. A major limitation of this study is that the control group was ventilated with tidal volumes of $10 \mathrm{ml} / \mathrm{kg}$ instead of the current low-volume ventilation standard per ARDSnet guidelines. The pig study might have had a negative result, had the researchers used a tidal volume of $6 \mathrm{ml} / \mathrm{kg}$ in their control group.

Neuromuscular blocking agents have been thought to aid in faster achievement of targeted lung-protective ventilation settings and patient synchrony with the ventilator. Papazian et al. [61] evaluated the effect of a 2day course of neuromuscular blocking agents in patients who developed severe ARDS requiring intubation within 48 hours of study enrollment. This randomized, doubleblinded trial in 20 multidisciplinary ICUs demonstrated a trend toward improved adjusted 90-day survival and increased time off the ventilator, especially in patients with a $\mathrm{PaO}_{2} / \mathrm{FiO}_{2}$ ratio less than 120 .

A systematic review of 33 randomized controlled trials came to the conclusion that the evidence to support pharmacological interventions, namely prostaglandin E1, $\mathrm{N}$-acetylcysteine, the early administration of high dose corticosteroids, or surfactant for ALI and ARDS is insufficient $[62,63]$.

Intermittent prone positioning therapy can improve oxygenation, but has failed to show a survival benefit except as rescue therapy in the severely hypoxemic ARDS patient with $\mathrm{P} / \mathrm{F}$ ratios of less than 100 (if measured in $\mathrm{mm} \mathrm{Hg}$ (less than 13 if measured in $\mathrm{kPa}$ ), but not in patients with $\mathrm{P} / \mathrm{F}$ ratios of greater than 100 if measured in $\mathrm{mm} \mathrm{Hg}$ (greater than 13 if measured in $\mathrm{kPa}$ ) [64-66].

Extracorporeal membrane oxygenation (ECMO) has been used in severe ARDS when the risks of refractory hypoxemia outweigh the risks of this invasive procedure. Although an early NIH study showed a greater volume of blood lost due to systemic coagulation in ECMO patients and no mortality benefit [67], more recent studies have demonstrated improved survival with ECMO in patients following traumatic injury $[68,69]$. The availability of heparin-bonded circuitry can negate the need for systemic anticoagulation for several days in patients following injury that in the majority of cases is performed with systemic anticoagulation [70]. Newer, mobile, and more compact circuits allow for the use of this lifesaving intervention in far-forward military locales and during military transport [71].

Rib fractures are detected in 10\% of trauma admissions. In $6 \%$ of patients after blunt chest injury, individual ribs are fractured in more than one place and allow paradoxical chest movement with respiration. Surgical management is controversial despite two level one evidence trials favoring operative fixation [72]. Tanaka et al. [73] and Granetzny et al. [74] reported significantly shorter durations of mechanical ventilation, length of stay in the ICU, and pneumonia with surgical fixation. A retrospective study in 1998 by Voggenreiter [75] had suggested that patients with pulmonary 
contusions did not benefit from surgical fixation as much as patients without pulmonary contusions did. This trend was also observed in a recent retrospective case-controlled study [76], but did not reach statistical significance. The controversy is further highlighted by two reports of improved pulmonary function testing results after surgical stabilization of flail chest at the 2012 Eastern Association for the Surgery of Trauma annual scientific meeting [77,78]. Large prospective randomized-controlled trials are needed for definite answers to relevant outcome questions.

\section{Conclusions and recommendations}

Acute lung injury and acute respiratory distress syndrome are heterogeneous diseases, the end result of many different types of acute pulmonary injury and with at times overlapping pathogenetic mechanisms [79]. Patients with trauma-associated lung injury have not received as much investigative attention as their medical and sepsis-afflicted counterparts with ALI/ARDS. Highlevel evidence to recommend ALI/ARDS management strategies tailored to this particular patient population is insufficient at this time.

Although there are several management strategies to improve oxygenation in patients on mechanical ventilation, decisions which therapies to use should be guided by meaningful outcome measures, including reduced duration of mechanical ventilation, length of ICU stay, and mortality [80].

Many trials examining the potential benefits of interventions have used mechanical ventilation strategies that are recognized as harmful today. Until recently, too many studies have failed to compare their intervention group to controls that reflect the current standard of care and mitigate progression of the lung injury. At a minimum, control groups should be ventilated with small tidal volumes as close to $6 \mathrm{ml} / \mathrm{kg}$ predicted body weight as patient comfort and ventilator synchrony permit, a minimum PEEP of $5 \mathrm{~cm} \mathrm{H}_{2} \mathrm{O}$, and plateau pressures less than or equal to $30 \mathrm{~cm} \mathrm{H}_{2} \mathrm{O}$ per existing guidelines for all patients with ALI/ARDS [81]. While we await future trials, we as clinicians can incorporate what has been shown to save lives a decade ago: lung protective ventilation.

\section{Competing interests}

The authors declare that they have no competing interests.

\section{Authors' contributions}

$\mathrm{MB}$ and $\mathrm{BB}$ contributed to the literature reviews, manuscript composition and editing. MM contributed to manuscript composition, editing and was responsible for the final product. All authors have read and approved the final manuscript.

\section{Author details}

${ }^{1}$ Department of Anesthesiology \& Critical Care, University of Pennsylvania,

3400 Spruce Street, Philadelphia, PA 19104, USA. ²Division of Traumatology,
Surgical Critical Care and Emergency Surgery, University of Pennsylvania, 3400 Spruce Street, Philadelphia, PA 19104, USA. ${ }^{3}$ Department of

Anesthesiology \& Critical Care, University of Pennsylvania, 3400 Spruce Street, Philadelphia, PA 19104, USA.

Received: 8 February 2012 Accepted: 11 June 2012

Published: 10 August 2012

\section{References}

1. Ashbaugh DG, Bigelow DB, Petty $T L$, Levine $B E$ : Acute respiratory distress in adults. Lancet 1967, 2(7511):319-323.

2. Vincent $\lrcorner$, Zambon $M$ : Why do patients who have acute lung injury/ acute respiratory distress syndrome die from multiple organ dysfunction syndrome? Implications for management. Clin Chest Med 2006, 27(4):725-731. abstract x-xi.

3. Cheung AM, Tansey CM, Tomlinson G, Diaz-Granados N, Matte A, Barr A, Mehta S, Mazer CD, Guest CB, Stewart TE, Al-Saidi F, Cooper AB, Cook D, Slutsky AS, Herridge MS: Two-year outcomes, health care use, and costs of survivors of acute respiratory distress syndrome. Am J Respir Crit Care Med 2006, 174(5):538-544.

4. Carson SS, Bach PB: The epidemiology and costs of chronic critical illness. Crit Care Clin 2002, 18(3):461-476.

5. Bernard GR, Artigas A, Brigham KL, Carlet J, Falke K, Hudson L, Lamy M, Legall JR, Morris A, Spragg R: The American-European consensus conference on ARDS. definitions, mechanisms, relevant outcomes, and clinical trial coordination. Am J Respir Crit Care Med 1994, 149(3 Pt 1):818-824.

6. Villar J, Perez-Mendez L, Lopez J, Belda J, Blanco J, Saralegui I, Suarez-Sipmann F, Lopez J, Lubillo S, Kacmarek RM, HELP Network: An early PEEP/FIO2 trial identifies different degrees of lung injury in patients with acute respiratory distress syndrome. Am J Respir Crit Care Med 2007, 176(8):795-804.

7. Britos M, Smoot E, Liu KD, Thompson BT, Checkley W, Brower RG, National Institutes of Health Acute Respiratory Distress Syndrome Network Investigators: The value of positive end-expiratory pressure and Fio(2) criteria in the definition of the acute respiratory distress syndrome. Crit Care Med 2011, 39(9):2025-2030.

8. Rubenfeld GD, Caldwell E, Peabody E, Weaver J, Martin DP, Neff M, Stern EJ, Hudson LD: Incidence and outcomes of acute lung injury. N Engl J Med 2005, 353(16):1685-1693

9. Navarrete-Navarro P, Rodriguez A, Reynolds N, West R, Rivera R, Scalea T: Adult respiratory distress syndrome among blunt and penetrating trauma patients: demographics, mortality, and resource utilization over 8 years. J Crit Care 2001, 16(2):47-53.

10. Zambon M, Vincent $\mathrm{J}$ : Mortality rates for patients with acute lung injury/ ARDS have decreased over time. Chest 2008, 133(5):1120-1127.

11. Erickson SE, Martin GS, Davis JL, Matthay MA, Eisner MD, NIH NHLBI ARDS Network: Recent trends in acute lung injury mortality: 1996-2005. Crit Care Med 2009, 37(5):1574-1579.

12. Hoyt DB, Simons RK, Winchell RJ, Cushman J, Hollingsworth-Fridlund P Holbrook T, Fortlage D: A risk analysis of pulmonary complications following major trauma. J Trauma 1993, 35(4):524-531.

13. Hudson LD, Milberg JA, Anardi D, Maunder RJ: Clinical risks for development of the acute respiratory distress syndrome. Am J Respir Crit Care Med 1995, 151(2 Pt 1):293-301.

14. Ciesla DJ, Moore EE, Johnson JL, Cothren CC, Banerjee A, Burch JM, Sauaia $A$ : Decreased progression of postinjury lung dysfunction to the acute respiratory distress syndrome and multiple organ failure. Surgery 2006, 140(4):640-647. discussion 647-8.

15. Recinos G, DuBose JJ, Teixeira PG, Barmparas G, Inaba K, Plurad D, Green DJ, Demetriades $D$, Belzberg $\mathrm{H}$ : ACS trauma centre designation and outcomes of post-traumatic ARDS: NTDB analysis and implications for trauma quality improvement. Injury 2009, 40(8):856-859.

16. Salim A, Martin M, Constantinou C, Sangthong B, Brown C, Kasotakis G, Demetriades $D$, Belzberg $H$ : Acute respiratory distress syndrome in the trauma intensive care unit: Morbid but not mortal. Arch Surg 2006, 141(7):655-658.

17. Treggiari MM, Hudson LD, Martin DP, Weiss NS, Caldwell E, Rubenfeld G: Effect of acute lung injury and acute respiratory distress syndrome on outcome in critically ill trauma patients. Crit Care Med 2004, 32(2):327-331.

18. Salim A, Martin M, Brown C, Inaba K, Browder T, Rhee P, Teixeira PG, Demetriades $D$ : The presence of the adult respiratory distress syndrome 
does not worsen mortality or discharge disability in blunt trauma patients with severe traumatic brain injury. Injury 2008, 39(1):30-35.

19. Calfee CS, Eisner MD, Ware LB, Thompson BT, Parsons PE, Wheeler AP, Korpak A, Matthay MA, Acute Respiratory Distress Syndrome Network, National Heart, Lung, and Blood Institute: Trauma-associated lung injury differs clinically and biologically from acute lung injury due to other clinical disorders. Crit Care Med 2007, 35(10):2243-2250.

20. Flori HR, Ware LB, Glidden D, Matthay MA: Early elevation of plasma soluble intercellular adhesion molecule-1 in pediatric acute lung injury identifies patients at increased risk of death and prolonged mechanical ventilation. Pediatr Crit Care Med 2003, 4(3):315-321.

21. Rubin DB, Wiener-Kronish JP, Murray JF, Green DR, Turner J, Luce JM, Montgomery AB, Marks JD, Matthay MA: Elevated von Willebrand factor antigen is an early plasma predictor of acute lung injury in nonpulmonary sepsis syndrome. J Clin Invest 1990, 86(2):474-480.

22. Moss M, Mannino DM: Race and gender differences in acute respiratory distress syndrome deaths in the United States: an analysis of multiplecause mortality data (1979-1996). Crit Care Med 2002, 30(8):1679-1685.

23. Zimmerman GA, Albertine KH, Carveth HJ, Gill EA, Grissom CK, Hoidal JR, Imaizumi T, Maloney CG, McIntyre TM, Michael JR, Orme JF, Prescott SM, Topham MS: Endothelial activation in ARDS. Chest 1999, 116(1 Suppl):18S-24S.

24. Miller PR, Croce MA, Kilgo PD, Scott J, Fabian TC: Acute respiratory distress syndrome in blunt trauma: identification of independent risk factors. Am Surg 2002, 68(10):845-850. discussion 850-1.

25. Wu J, Sheng L, Ma Y, Gu J, Zhang M, Gan J, Xu S, Jiang G: The analysis of risk factors of impacting mortality rate in severe multiple trauma patients with posttraumatic acute respiratory distress syndrome. Am J Emerg Med 2008, 26(4):419-424.

26. Navarrete-Navarro P, Rivera-Fernandez R, Rincon-Ferrari MD, Garcia-Delgado M, Munoz A, Jimenez JM, Ortega FJ, Garcia DM, GITAN multicenter project: Early markers of acute respiratory distress syndrome development in severe trauma patients. J Crit Care 2006, 21(3):253-258.

27. Croce MA, Fabian TC, Davis KA, Gavin TJ: J Trauma 1999, 46(3):361-366. discussion 366-8.

28. Ware LB: Pathophysiology of acute lung injury and the acute respiratory distress syndrome. Semin Respir Crit Care Med 2006, 27(4):337-349.

29. Ware LB, Matthay MA: The acute respiratory distress syndrome. N Engl J Med 2000, 342(18):1334-1349.

30. Chaiwat O, Lang JD, Vavilala MS, Wang J, MacKenzie EJ, Jurkovich GJ, Rivara FP: Early packed red blood cell transfusion and acute respiratory distress syndrome after trauma. Anesthesiology 2009, 110(2):351-360.

31. Silverboard H, Aisiku I, Martin GS, Adams M, Rozycki G, Moss M: The role of acute blood transfusion in the development of acute respiratory distress syndrome in patients with severe trauma. J Trauma 2005, 59(3):717-723.

32. Watson GA, Sperry JL, Rosengart MR, Minei JP, Harbrecht BG, Moore EE, Cuschieri J, Maier RV, Billiar TR, Peitzman AB, Inflammation and Host Response to Injury Investigators: Fresh frozen plasma is independently associated with a higher risk of multiple organ failure and acute respiratory distress syndrome. J Trauma 2009, 67(7):221. discussion 228-30.

33. Watkins TR, Rubenfeld GD, Martin TR, Nester TA, Caldwell E, Billgren J, Ruzinski J, Nathens AB: Effects of leukoreduced blood on acute lung injury after trauma: a randomized controlled trial. Crit Care Med 2008, 36(5):1493-1499.

34. Inaba K, Branco BC, Rhee P, Holcomb JB, Blackbourne LH, Shulman I, Nelson J, Demetriades D: Impact of ABO-identical vs ABO-compatible nonidentical plasma transfusion in trauma patients. Arch Surg 2010, 145(9):899-906.

35. Miller PR, Croce MA, Bee TK, Qaisi WG, Smith CP, Collins GL, Fabian TC: ARDS after pulmonary contusion: accurate measurement of contusion volume identifies high-risk patients. J Trauma 2001, 51(2):223-228. discussion 229-30

36. Wang S, Ruan Z, Zhang J, Jin W: The value of pulmonary contusion volume measurement with three-dimensional computed tomography in predicting acute respiratory distress syndrome development. Ann Thorac Surg 2011, 92(6):1977-1983.

37. Strumwasser A, Chu E, Yeung L, Miraflor E, Sadjadi J, Victorino GP: A novel $\mathrm{CT}$ volume index score correlates with outcomes in polytrauma patients with pulmonary contusion. J Surg Res 2011, 170(2):280-285.

38. Heffernan DS, Dossett LA, Lightfoot MA, Fremont RD, Ware LB, Sawyer RG, May AK: Gender and acute respiratory distress syndrome in critically injured adults: a prospective study. J Trauma 2011, 71(4):878-883. discussion 883-5.
39. Han S, Martin GS, Maloney JP, Shanholtz C, Barnes KC, Murray S, Sevransky JE: Short women with severe sepsis-related acute lung injury receive lung protective ventilation less frequently: an observational cohort study. Crit Care 2011, 15(6):R262.

40. Gadek JE, DeMichele SJ, Karlstad MD, Pacht ER, Donahoe M, Albertson TE, Van Hoozen C, Wennberg AK, Nelson JL, Noursalehi M: Effect of enteral feeding with eicosapentaenoic acid, gamma-linolenic acid, and antioxidants in patients with acute respiratory distress syndrome Enteral Nutrition in ARDS Study Group. Crit Care Med 1999, 27(8):1409-1420.

41. Rice TW, Wheeler AP, Thompson BT, deBoisblanc BP, Steingrub J, Rock P, NHLBI ARDS Clinical Trials Network: Enteral omega-3 fatty acid, gammalinolenic acid, and antioxidant supplementation in acute lung injury. JAMA 2011, 306(14):1574-1581.

42. Plurad D, Green D, Inaba K, Belzberg H, Demetriades D, Rhee P: A 6-year review of total parenteral nutrition use and association with late-onset acute respiratory distress syndrome among ventilated trauma victims. Injury 2009, 40(5):511-515.

43. National Heart, Lung and Blood Institute Acute Respiratory Distress Syndrome (ARDS) Clinical Trials Network, Wiedemann HP, Wheeler AP, Bernard GR, Thompson BT, DeBoisblanc B, Connors AF Jr: Comparison of two fluid-management strategies in acute lung injury. N Engl J Med 2006, 354(24):2564-2575.

44. Stewart RM, Park PK, Hunt JP, McIntyre RC Jr, McCarthy J, Zarzabal LA, Michalek JE, National Institutes of Health/National Heart, Lung, and Blood Institute Acute Respiratory Distress Syndrome Clinical Trials Network: Less is more: improved outcomes in surgical patients with conservative fluid administration and central venous catheter monitoring. J Am Coll Surg 2009, 208(5):725-735. discussion 735-7.

45. Todd SR, McNally MM, Holcomb JB, Kozar RA, Kao LS, Gonzalez EA Cocanour CS, Vercruysse GA, Lygas MH, Brasseaux BK, Moore FA: A multidisciplinary clinical pathway decreases rib fracture-associated infectious morbidity and mortality in high-risk trauma patients. The American Journal of Surgery 2006, 192(6):806-811.

46. Hodgson C, Keating JL, Holland AE, Davies AR, Smirneos L, Bradley SJ, Tuxen $D$ : Recruitment manoeuvres for adults with acute lung injury receiving mechanical ventilation. Cochrane Database Syst Rev 2009, 2(2):CD006667.

47. Vidhani K, Kause J, Parr M: Should we follow ATLS guidelines for the management of traumatic pulmonary contusion: the role of noninvasive ventilatory support. Resuscitation 2002, 52(3):265-268.

48. Hernandez G, Fernandez R, Lopez-Reina P, Cuena R, Pedrosa A, Ortiz R, Hiradier $P$ : Noninvasive ventilation reduces intubation in chest traumarelated hypoxemia. Chest 2010, 137(1):74-80.

49. Amato MB, Barbas CS, Medeiros DM, Magaldi RB, Schettino GP, Lorenzi-Filho G, Kairalla RA, Deheinzelin D, Munoz C, Oliveira R, Takagaki TY, Carvalho CR: Effect of a protective-ventilation strategy on mortality in the acute respiratory distress syndrome. N Engl J Med 1998, 338(6):347-354.

50. The Acute Respiratory Distress Syndrome Network: Ventilation with Lower Tidal Volumes as Compared with Traditional Tidal Volumes for Acute Lung Injury and the Acute Respiratory Distress Syndrome. N Engl J Med 2000, 342(18):1301-1308.

51. Richard JC, Brochard L, Vandelet P, Breton L, Maggiore SM, Jonson B, Clabault K, Leroy J, Bonmarchand G: Respective effects of end-expiratory and end-inspiratory pressures on alveolar recruitment in acute lung injury. Crit Care Med 2003, 31(1):89-92.

52. Borges JB, Okamoto VN, Matos GF, Caramez MP, Arantes PR, Barros F, Souza CE, Victorino JA, Kacmarek RM, Barbas CS, Carvalho CR, Amato MB: Reversibility of lung collapse and hypoxemia in early acute respiratory distress syndrome. Am J Respir Crit Care Med 2006, 174(3):268-278.

53. Meade MO, Cook DJ, Guyatt GH, Slutsky AS, Arabi YM, Cooper DJ, Davies AR, Hand LE, Zhou Q, Thabane L, Austin P, Lapinsky S, Baxter A, Russell J, Skrobik Y, Ronco JJ, Stewart TE, Lung Open Ventilation Study Investigators: Ventilation strategy using low tidal volumes, recruitment maneuvers, and high positive end-expiratory pressure for acute lung injury and acute respiratory distress syndrome: a randomized controlled trial. JAMA 2008, 299(6):637-645

54. Santa Cruz R, Rojas Juan I, Nervi R, Heredia R, Ciapponi A: High versus low positive end-expiratory pressures (PEEP) levels for mechanically ventilated adult patients with acute lung injury and acute respiratory distress syndrome. 2011, 5 . 
55. Dasenbrook EC, Needham DM, Brower RG, Fan E: Higher PEEP in patients with acute lung injury: a systematic review and meta-analysis. Respir Care 2011, 56(5):568-575.

56. Kiraly L, Schreiber M: Management of the crushed chest. Crit Care Med 2010, 38(9 Suppl):S469-S477.

57. Sud S, Sud M, Friedrich JO, Meade MO, Ferguson ND, Wunsch H, Adhikari NK: High frequency oscillation in patients with acute lung injury and acute respiratory distress syndrome (ARDS): systematic review and metaanalysis. BMJ 2010, 340:c2327.

58. Maung AA, Kaplan LJ: Airway pressure release ventilation in acute respiratory distress syndrome. Crit Care Clin 2011, 27(3):501-509.

59. Maclntyre N: Airway pressure release ventilation: hope or hype? Crit Care Med 2011, 39(10):2376-2377.

60. Roy SK, Kuhn M, Sadowitz BD, Habashi NM, Andrews P, Gatto LA, Vodovotz Y, Marx W, Nieman GF: Preventative Ventilation Prior To Lung Injury Averts ARDS: A Novel Timing-Based Strategy Of Ventilator Therapy. [abstract]. Annual Scientific Assembly: Eastern Association for the Surgery of Trauma. Lake Buena Vista, FL; 2012. Jan 10-14.

61. Papazian L, Forel JM, Gacouin A, Penot-Ragon C, Perrin G, Loundou A, Jaber S, Arnal JM, Perez D, Seghboyan JM, Constantin JM, Courant P, Lefrant JY, Guérin C, Prat G, Morange S, Roch A: Neuromuscular blockers in early acute respiratory distress syndrome. N Engl J Med 2010, 363(12):1107-1116.

62. Adhikari N, Burns KE, Meade MO: Pharmacologic therapies for adults with acute lung injury and acute respiratory distress syndrome. Cochrane Database Syst Rev 2004, 4(4):CD004477.

63. Afshari A, Brok J, Moller AM, Wetterslev J: Aerosolized prostacyclin for acute lung injury (ALI) and acute respiratory distress syndrome (ARDS). Cochrane Database Syst Rev 2010, 8(8):CD007733.

64. Gattinoni L, Tognoni G, Pesenti A, Taccone P, Mascheroni D, Labarta V, Malacrida R, Di Giulio P, Fumagalli R, Pelosi P, Brazzi L, Latini R, Prone-Supine Study Group: Effect of prone positioning on the survival of patients with acute respiratory failure. N Engl J Med 2001, 345(8):568-573.

65. Walkey AJ, Wiener RS: Utilization patterns and patient outcomes associated with use of rescue therapies in acute lung injury. Crit Care Med 2011, 39(6):1322-1328.

66. Gattinoni L, Carlesso E, Taccone P, Polli F, Guerin C, Mancebo J: Prone positioning improves survival in severe ARDS: a pathophysiologic review and individual patient meta-analysis. Minerva Anestesio/ 2010, 76(6):448-454.

67. Zapol WM, Snider MT, Hill JD, Fallat RJ, Bartlett RH, Edmunds LH, Morris AH, Peirce EC 2nd, Thomas AN, Proctor HJ, Drinker PA, Pratt PC, Bagniewski A, Miller RG Jr: Extracorporeal membrane oxygenation in severe acute respiratory failure. A randomized prospective study. JAMA 1979, 242(20):2193-2196.

68. Cordell-Smith JA, Roberts N, Peek GJ, Firmin RK: Traumatic lung injury treated by extracorporeal membrane oxygenation (ECMO). Injury 2006, 37(1):29-32.

69. Madershahian N, Wittwer T, Strauch J, Franke UF, Wippermann J, Kaluza M, Wahlers T: Application of ECMO in multitrauma patients with ARDS as rescue therapy. J Card Surg 2007, 22(3):180-184.

70. Reynolds HN, Cottingham C, McCunn M, Habashi NM, Scalea TM: Extracorporeal lung support in a patient with traumatic brain injury: the benefit of heparin-bonded circuitry. Perfusion 1999, 14(6):489-493.

71. Allan PF, Osborn EC, Bloom BB, Wanek S, Cannon JW: The introduction of extracorporeal membrane oxygenation to aeromedical evacuation. Mil Med 2011, 176(8):932-937.

72. Fitzpatrick DC, Denard PJ, Phelan D, Long WB, Madey SM, Bottlang M: Operative stabilization of flail chest injuries: review of literature and fixation options. Eur J Trauma Emerg Surg 2010, 36(5):427-433.

73. Tanaka H, Yukioka T, Yamaguti Y, Shimizu S, Goto H, Matsuda H, Shimazaki S: Surgical stabilization of internal pneumatic stabilization? A prospective randomized study of management of severe flail chest patients. J Trauma 2002, 52(4):727-732. discussion 732.

74. Granetzny A, Abd El-Aal M, Emam E, Shalaby A, Boseila A: Surgical versus conservative treatment of flail chest. Evaluation of the pulmonary status. Interact Cardiovasc Thorac Surg 2005, 4(6):583-587.

75. Voggenreiter G, Neudeck F, Aufmkolk M, Obertacke U, Schmit-Neuerburg KP: Operative chest wall stabilization in flail chest-outcomes of patients with or without pulmonary contusion. J Am Coll Surg 1998, 187(2):130-138.

76. Althausen $\mathrm{PL}$, Shannon S, Watts C, Thomas K, Bain MA, Coll D, O'mara TJ, Bray TJ: Early surgical stabilization of flail chest with locked plate fixation. J Orthop Trauma 2011, 25(11):641-647.
77. Hamilton DA, Orr NT, Boulanger BR, Bernard AC, Chang PK, Kearney PA, Hasenboehler E: Evaluation of patient vital capacity and pain following rib open reduction internal fixation for flail chest [abstract]. Annual Scientific Assembly: Eastern Association for the Surgery of Trauma. Lake Buena Vista, FL; 2012. Jan 10-14.

78. Said SM, Kim BD, Goussous N, Zielinski MD, Schiller HJ: Surgical stabilization of flail chest: the impact on postoperative pulmonary function. [abstract]. Annual Scientific Assembly: Eastern Association for the Surgery of Trauma. Lake Buena Vista, FL; 2012. Jan 10-14.

79. Willson DF, Notter RH: The future of exogenous surfactant therapy. Respir Care 2011, 56(9):1369-1386. discussion 1386-8.

80. Raoof S, Goulet K, Esan A, Hess DR, Sessler CN: Severe hypoxemic respiratory failure: part 2-nonventilatory strategies. Chest 2010, 137(6):1437-1448.

81. [http://www.ardsnet.org/node/77791].

\section{doi:10.1186/1757-7241-20-54}

Cite this article as: Bakowitz et al:: Acute lung injury and the acute respiratory distress syndrome in the injured patient. Scandinavian Journal of Trauma, Resuscitation and Emergency Medicine 2012 20:54.

\section{Submit your next manuscript to BioMed Central and take full advantage of:}

- Convenient online submission

- Thorough peer review

- No space constraints or color figure charges

- Immediate publication on acceptance

- Inclusion in PubMed, CAS, Scopus and Google Scholar

- Research which is freely available for redistribution 